\title{
WILLIAM GEORGE MORROW
}

\author{
W. H. HURLBURT* and W. A. STEVENSON**
}

\section{INTRODUCTION}

It is fitting that the last paper intended for publication by the late $\mathrm{Mr}$. Justice W. G. Morrow should be accompanied by some remarks about him and by a brief description of his remarkable professional career. ${ }^{1}$ The reason that is it fitting is that the paper reflects many of the qualities that earned its author a place of lasting respect and affection in the legal profession: it reflects his interest in the publication of legal scholarship; his interest in the efforts of the young members of the profession; his interest in the history of this province; and his interest in the role of the law in the development of society.

Bill Morrow was admitted to the practice of law in 1940 by $\mathrm{Mr}$. Justice Ives (who had admitted his father to practice 25 years before). His professional career was interrupted by the Second World War and his service in the Navy. It resumed in 1945 when he returned to the private practice of law, in which he continued until 1966. It continued with his appointment to the Territorial Court (later the Supreme Court) of the Northwest Territories, where he served until 1976, and with his appointment to the Appellate Division of the Supreme Court of Alberta in that year. It ended with his untimely death in August, 1980.

His career was marked by a restless quality which included an insatiable curiosity and a desire to have new experiences and to try himself in different ways. Throughout his life unusual and apparently fortuitous events occurred around him, but closer examination would usually trace each of them back to something that he had previously done or was doing at the time. His appointment to the Territorial Court, for example, had its roots in his decision in 1960 to accompany the late Mr. Justice J.H. Sissons as unpaid defence counsel on one of the arduous and extensive Arctic circuits which that doughty judge habitually undertook. He was retained in $R$. v. $A$ yalik ${ }^{2}$ but the retainer came after he had already decided to make the circuit. He was acutely conscious of the importance of law and justice and of the functions of lawyer and judge. As a redoubtable opponent and valued colleague has said of him: ${ }^{3}$

Bill was a true crusader for the underdog with none of the self-aggrandizement that such people sometimes have. He was a gentle man, a kindly man, a compassionate man. He was a prodigious worker, a superb legal practitioner, a scholar. He had a keen sense of the ridiculous and was a great raconteur. I lost track of him somewhat during his years in the North where he left such a lasting imprint on that land and its people. I came to know him again as a colleague whom I consulted as much as anyone on the bench. We shall miss him more than I can say.

- Director, The Institute of Law Research and Reform, Edmonton, and a former partner of W.G. Morrow in the practice of law.

** Of the Court of Appeal of Alberta; and also a former partner of W.G. Morrow.

1. The authors do not intend to conceal the affectionate esteem in which they hold him.

2. (1960) 33 W.W.R. 377.

3. Hon. Mr. Justice J.H. Laycraft, Address to the Alberta Law Review 14th annual dinner. March 5, 1981. 
As a lawyer Bill Morrow gave no opponent grounds to complain of unfairness and he gave no client grounds to complain of the lack of a vigorous assertion or defence of the client's rights. He thought the law and the legal system should give everyone an equal opportunity and treat everyone fairly; he was never happier than when he was asserting (quite frequently at his own expense) the rights of someone who was being unfairly treated. As a judge he was willing to undergo hardship and even danger to see that justice was brought to the most remote of settlements. He was a fighter: as a lawyer he was prepared to assert his client's rights even if doing so put him personally at risk with the court; and as a judge he was prepared to use every honourable resource of his office to see justice done and to protect the standing of his court. But he was first a peacemaker: he always went as far as he could to avoid confrontation, to achieve negotiated or peaceful settlements and to give those with whom he was involved a way to settle or to do what they should do without unnecessary loss of face. In money matters he was generous to a fault; he often took on cases where there was little or no chance of financial return, and his generosity to those around him was notable.

On the other hand, he had a strong practical sense. He tilted at real wrongs, not at windmills. The idealism which animated many of his actions was balanced by a practical sense of what was possible and how it could best be achieved. His goals were worth the trouble and risk which he underwent to achieve them.

As a lawyer, Bill Morrow made the kind of contribution which leading counsel may be expected to make; that is, he provided the legal advice and representation which is necessary if people's rights are to be properly maintained inside and outside of the courts. This he did extremely well and in an unusual volume. Also as good counsel do, he contributed to the case-by-case evolution of the law. His special contribution as a lawyer, however, was his willingness to undertake unprofitable and unpopular causes and thereby to vindicate the legal system. As a judge, he made the kind of contribution which strong judges may be expected to make; that is, he gave everyone a fair and impartial hearing and a fair and impartial adjudication. Again as good judges do, he gave reasoned judgments which again contributed to the case-by-case evolution of the law. His special contribution as a judge, however, was the way in which he helped to apply the law and fashion the administration of justice to the peculiar circumstances of the North and of its people. Creativity and a willingness to innovate, balanced by a respect for the law and the administration of justice marked all aspects of his career.

\section{EARLY LIFE}

Bill was the son of a lawyer, William Morrow. The elder Morrow was a sincere, conscientious, well regarded member of the bar whose practice would today be described as a conveyancing practice but whose relationship to his clients was that of trusted counsellor. His clientele consisted largely of working people, a great many of whom came from farms. Both William Morrow and his wife Opal had themselves farmed and had a love of the land which they instilled in their son. Young Bill spent many of his summers as a youth on the family farm in Manitoba or helping farm clients here in Alberta. He never talked to a farm client without get- 
ting into a discussion about the conditions of agriculture in the community.

The elder Morrow was a successful practitioner but in western Canada few were unaffected by the depression and his son frequently referred to some of his father's old account books which showed a net cash income in some months of twenty or thirty dollars. Although these were lean years for the family, Morrow was always quick to point out that he was never in need and that there was never any doubt that he would be able to obtain a university education.

Bill studied law at the University of Alberta. Throughout his life he frequently recalled the exhilarating experience of being taught by the late John Weir and by Malcolm McIntyre. He was well taught; he never lost the ability to research a point of law, nor did he ever forget a principle that those early lecturers taught him.

\section{THE WAR YEARS}

Bill joined the navy in 1942 . He threw himself into the navy life, as into everything else he ever did, with great enthusiasm. He always remembered those days with great affection and often remarked that he might have stayed in the navy had he not felt a responsibility to return to his father, who had maintained the practice during the war at considerable cost to his own health. He sought an active role and most of his active service was on minesweepers. Indeed, on D-Day, with the allied forces, Lieutenant W.G. Morrow was second officer on H.M.C.S. Georgian, one of the first minesweepers in the invasion flotilla. It was expected that as many as a third of the minesweepers would be lost in the first onslaught. That chilling fact would give most of us some appreciation of the risks that were involved, and yet, when he was asked, Morrow would quickly respond that he enjoyed every minute of his navy life. His life in the navy, like his life in the battles of the courtroom, reflected a romantic love of adventure coupled with determination - qualities which he often observed were attributable to his Irish ancestry. Another Irish quality which showed itself during the war years and later was that of imagination. These qualities marked his approach to the serious business of the navy, but they also marked his approach to the lighter side. Upon one occasion, having been reprimanded for taking photographs, he studied the fleet orders and was pleased to find that a photograph permit could be obtained for the designated officer of a ship. He accordingly arranged for his captain to have him appointed official photographer of the ship and was one of the few to come out of the war with pictures taken in action, indeed, a unique collection.

\section{THE LAWYER}

Bill Morrow practised for a time before his war service intervened. Unlike his father he decided to try his hand at litigation. He felt the need to establish his own individual position rather than remain in the shadow of his father and he also wanted to complement his father's area of practice. But it is likely that the real reason was that litigation was "the only civilized way in which an Irishman could indulge in his inherent desire for contest - his desire to fight". His father agreed that Morrow could undertake any cause he felt deserving, regardless of ability to pay. He often represented citizens of limited means on the understanding that he 
would not be paid unless there was some recovery, and a good many of those cases involved no prospect of financial recovery.

When Bill Morrow joined his father in 1940, the effects of the depression were still apparent. Since many of the elder Morrow's clients had lent money on farm land security, Morrow undertook to master The Farmers' Creditors Arrangement Act and appeared often in applications under that Act. His first difficult task was to persuade a Board of Review under the chairmanship of the redoubtable Chief Justice Mitchell that the Board had no jurisdiction under the Act where a farmer had after 1935 assumed a mortgage which had been in force before 1935 . He also undertook needy litigant cases which at that time paid no fees.

By the time he returned to practice in 1945, war-time rent control regulations had become important and the first reported decision in which he was counsel is one in which he persuaded the Appellate Division that a house located on land used solely for agricultural purposes was itself exempted from the rent control regulations even though the house had been let separately from the land and not in connection with the farming operation. ${ }^{4}$ His energy and ability quickly brought him a good deal of work, and within three years of his return to practice there are three reported appeals in which he took part..$^{5}$ As his name became known he began to receive referral work from other lawyers, and by 1950 he was well known in the Appellate Divison of the Supreme Court of Alberta as well as in the Trial Division.

During the two decades from 1945 to 1965 Bill Morrow handled a large volume of interesting and important litigation. He appeared before every court in Alberta. He also appeared in British Columbia and the Northwest Territories and in the Federal Court and its predecessor. He appeared before the Supreme Court of Canada on 21 appeals and 10 applications for leave to appeal. He argued the last case from Canada to reach the Judicial Committee of the Privy Council.

His cases covered the spectrum of civil litigation and included criminal cases as well. He became involved in the early oil litigation in Alberta, in part because he drew the lease upon which A tlantic No. 3, the well known wild well, was drilled, and because he dealt with the legal complications which followed when the well went out of control. Examples of his oil litigation are Oil City Petroleums (Leduc) Ltd. v. American Leduc Petroleums $L t d .{ }^{6}$ in which on his application the Clerk of the Court acted as receiver and was responsible for the drilling of an oil well on the property in dispute, and Earl F. Wakefield Co. v. Oil City Petroleums Ltd. ${ }^{7}$ dealing with a mechanic's lien on an oil well. He was also involved in major cases involving real property generally: he appears in the law reports in Western Minerals Ltd. v. Gaumont and Brown ${ }^{8}$ in which it was held that sand and gravel go with the surface title rather than the mineral title; in

4. Lefor v. Parson and Parson [1947] 1 D.L.R. 627.

5. Moreau v. Baker and Moret [1947] 3 D.L.R. 537; Bowyer v. Wylie and Burton [1948] 3 D.L.R. 234; and Lefor v. Parson supra n. 4.

6. [1952] 3 D.L.R. 577 .

7. [1959] 29 W.W.R. 638.

8. [1953] S.C.R. 345. 
Kaup and Kaup v. Imperial Oil Limited ${ }^{9}$ in which it was held that the land titles system does not protect a volunteer; in Meduk v. Soja ${ }^{10}$ in which it was held that a contract for the sale of land not consented to by the spouse of the registered owner was illegal under The Dower Act; in British American Oil Co. Ltd. v. Kos ${ }^{11}$ in which it was held that a mortgage with a forged dower consent was void under The Dower Act and that the spouse whose signature was forged could not be estopped by subsequent conduct; in Krook v. Yewchuk ${ }^{12}$ in which it was held that the bar against actions on a personal covenant under section 34(1)(a) of The Judicature Act does not prevent the enforcement of a collateral chattel mortgage; in Credit Foncier Franco-Canadien v. Edmonton Airport Hotel ${ }^{13}$ in which it was held that the same provision did not prevent the mortgagee from suing upon a personal guarantee; in Canadian Construction Co. Ltd. v. Beaver (Alberta) Lumber Ltd. ${ }^{14}$ in which it was held that a restrictive covenant against the use of land was personal to the vendor; and in $R u p$ tash and Lumsden v. Zawick ${ }^{15}$ in which it was held that a caveat under The Land Titles Act does not protect an interest not referred to in it. Though motor vehicle litigation was not one of his great interests, he took his share of such cases; for example: Rehn v. McLean; ${ }^{16} \operatorname{Bedry}$ v. Bonin; ${ }^{17}$ Stene v. Evans; ${ }^{18}$ Maze v. Empson ${ }^{19}$ and Dearing v. Hebert..$^{20} \mathrm{He}$ was involved in expropriation cases both for land owners and expropriating authorities. In Northland Utilities v. Grande Prairie ${ }^{21}$ he undertook the difficult procedural and substantive problems raised by the rights of municipalities to purchase gas utilities franchised by them. These are only examples of a wide-ranging litigation practice. Somehow, however, he always managed to do a substantial volume of solicitor's work as well, ranging from the incorporation of private companies through contract and commercial work and advice on media publications to the administration of estates.

Bill Morrow was invariably respectful of the tribunal before which he appeared. However he was quite prepared to take issue with the tribunal when his client's interests required him to do so. It was not unknown for him, when delay in judgment was to his client's prejudice, to invite the judge to give judgment against him so that he could get on with the appeal. On one occasion he had the state police of an American state looking for a judge who had not delivered an urgently needed judgment before leaving on vacation. On another occasion, when called as a witness in a law-

9. (1962) 37 W.W.R. 193.

10. [1958] S.C.R. 167.

11. (1963) 46 W.W.R. 141.

12. (1962) 39 W.W.R. 13.

13. [1965] S.C.R. 441.

14. [1955] 3 D.L.R. 502 .

15. (1956) 2 D.L.R. (2d) 145.

16. (1958) 24 W.W.R. 241.

17. (1958) 24 W.W.R. 473.

18. (1958) 24 W.W.R. 593.

19. (1964) 48 W.W.R. 59.

20. [1957] S.C.R. 843 .

21. (1966) 56 W.W.R. 613. 
suit arising out of a transaction which he had negotiated, Morrow decided that the court would have to hear what he would have to say as witness although he thought that in so doing he would be running a substantial risk of being committed for contempt in the highly charged circumstances that existed, an expectation which fortunately did not become an actuality. On another occasion he appeared for a man who was alleged to be the distributor of gasoline in a conspiracy to defraud the government of gasoline tax. The allegation was that the conspirators paid tax on the gasoline at the lower agricultural rate but contrived to get delivery of it and sell it without the purple dye which would prevent its sale for ordinary use at ordinary prices. In the course of the argument of the appeal from conviction, a member of the bench said: "We've got to get the distributor, Mr. Morrow". Morrow's reply was "Surely, My Lord, those remarks were more appropriate for the Chief of Police than one of Her Majesty's justices". Fortunately the judge was a fine gentleman and a great judge and perceived the justness of the rejoinder.

It always pleased the Irish in him to make a point. He always fondly remembered, for example, Moreau v. Baker and More $t^{22}$ in which he was able to establish by a successful appeal that no formality was needed to get before the court in order to obtain a certificate of payment of a mortgage under the informal procedure envisioned by The Land Titles Act. It was even more important to him to make the point when he thought that his client had been oppressed. A notable example is the case of Joncas $\mathrm{v}$. Pennock. In that case a lawyer had acquired property previously belonging to his client. Years later the client's daughter commenced proceedings against the lawyer but unfortunately did not commence them properly; her action was dismissed at trial and upon appeal. Bill Morrow, who had as a last resort acted on the appeal, ${ }^{23}$ then recommenced the action properly and it was followed through to a successful conclusion. ${ }^{24}$ The case was something of a cause célèbre and the result was a vindication of the legal system.

His strategies and tactics, where the circumstances were appropriate, were bold and innovative; he went for the essential point and tried to clear away the underbrush which would obscure his client's essential position. In a dispute over who was entitled to oil leases which were running out, for example, it was his client who put up the money to allow the Clerk of the Court, in an unusual if not unprecedented receivership, to drill a well to save them. When a will in effect gave his client a right of first refusal over the testator's shares in a company, at the crucial point Bill delivered a letter to the executor saying that his client would match any offer made by the rival claimant. His "with prejudice" letters setting out his client's position both for negotiation and for the record were well known in the legal profession.

The activities which were most characteristic of the man were those related to the North. We have mentioned the arrangement which he made in 1960 to go as volunteer defence counsel on a circuit with the Territorial

\footnotetext{
22. Supra n. 5.

23. (1959) 27 W.W.R. 174.

24. (1961)37 W.W.R. 134.
} 
judge of the Northwest Territories, Mr. Justice J.H. Sissons, an arrangement which offered no material rewards and promised him only some arduous, unpaid and highly uncomfortable weeks in a strange, difficult and dangerous environment. The federal government, however, retained him to act as defence counsel for an Eskimo who, having been taken into custody for drunkenness, shot and killed an R.C.M.P. constable under tragic circumstances. The jury found the Eskimo guilty of manslaughter rather than murder and the Crown appealed the sentence of five years imposed by Mr. Justice Sisson. At the suggestion of Morrow, innovative as always, the Court of Appeal agreed to sit for the first time at Yellowknife, and it dismissed the appeal. ${ }^{25} \mathrm{He}$ noted for the future the court's reference to the advantage of the trial judge over the members of the Court of Appeal in sentencing: "... for with his wide experience in the far-flung areas of the extensive jurisdiction of the trial division of this court he has knowledge of local conditions, ways of life, habits, customs and characteristics of the race of people of which the accused is a member". ${ }^{26}$ During the next few years Bill returned frequently to the North. In 1961 he argued the case of Re Noah Estate ${ }^{27}$ in which Mr. Justice Sissons held that a marriage in accordance with Eskimo custom is a marriage recognized by the common law so that a child of the marriage was entitled to inherit from the father. In 1965 he acted for the nephew of a woman who had gone mad and had been killed by decision of her group as a matter of survival; his client was convicted but under the circumstances given a suspended sentence. ${ }^{28}$

The most important of the northern cases Bill Morrow undertook as a lawyer were two which involved the hunting rights of the native peoples. In Sigeareak v. $R \cdot{ }^{29}$ he argued unsuccessfully that the game ordinance of the Northwest Territories did not apply to Eskimos, basing his argument largely on the Royal Proclamation of 1763 which was intended to protect Indians in their traditional rights. The second case, which, in spirit if not in law was a precursor of his own decision as a judge in Regina v. Drybones ${ }^{30}$ was Sikyea v. $R .{ }^{31}$ Michael Sikyea, a treaty Indian, had shot a duck for food and had been convicted of an offence against the regulations made under the Migratory Birds Convention Act. Morrow attacked that Act itself but the Appellate Division and the Supreme Court of Canada, while they recognized that the Act was a breach of treaties with the Indians, held that Parliament had the power to pass it.

Throughout the period of his practice, Bill Morrow was routinely consulted on matters of practice and ethics by other members of the bar, and he appeared (unpaid) for members of the bar on several occasions in disciplinary proceedings of the Law Society. He devoted much time to juniors and students. No student or junior lawyer in his office was denied the opportunity to discuss professional problems - indeed, Morrow

\footnotetext{
25. $\quad R$. v. A yalik supra n. 2.

26. Id. at 379 .

27. (1961) 36 W.W.R. 577.

28. $R$. v. Shooyuk (unreported).

29. (1966) 56 W.W.R. 478.

30. (1967) 60 W.W.R. 321.

31. (1964) 49 W.W.R. 306.
} 
would defer his own work to discuss at leisure, at the convenience of others, their own particular problems. He felt very strongly that lawyers, as members of a learned profession, have a clear obligation to devote themselves to public service. Not content with the contribution which he made to the public through what could only today be described as a private legal aid programme, he sought to serve the community in other ways. He was a member of the Edmonton Public School Board; he sought nomination as a candidate for Parliament; and he served as a bencher of the Law Society and was heavily involved in the implementation and organization of the Alberta Legal Aid Plan. He was the first Canadian director of the American Judicature Society, a large and well known organization devoted to the efficient administration of justice. One wonders where he found the time to do all that he did. The answer is that he did so by sacrificing virtually all of his leisure time. He routinely worked seven days a week and it was only on Saturday and Sunday evenings, and not all of those, that the lights in his office in the McLeod Building were not alight long after the supper hour.

\section{THE JUDGE}

In 1966 he accepted an appointment to the Territorial Court of the Northwest Territories, which later became the Supreme Court. He took the appointment because of a sense of duty and obligation and at some considerable sacrifice to himself and his family. In retrospect, the choice, though in the public interest, may not have been in his personal interest; it is likely that he was happier in the hectic life of a lawyer in private practice than in the more isolated though still demanding life of a judge. But it is in the latter capacity that he made his greatest contribution to the life of the country.

It is not possible to deal adequately with the great range of work which "Judge" Morrow did during his 10 years in the Northwest Territories. He shared the view of Mr. Justice J.H. Sissons, that the court should go to the people, notwithstanding the vastness of the area under his jurisdiction and the sparseness of its population; and he applied all his vigour and determination to discharging the responsibilities he took up from his valiant predecessor. A Chief Court Reporter was heard to say ruefully: "[Morrow] not only maintained as onerous a schedule as Mr. Justice Sissons had established but unlike Sissons [who was older and had to struggle with physical disability] he made you run to the plane". Morrow's time was a time of travelling long distances by airplane, in conditions which were usually uncomfortable and often dangerous, of holding court in whatever space was available, and living wherever he could. He was much concerned to apply the white man's law fairly to the native peoples, taking into account the differences in the cultures and life expectancies and the great strain that the incursion of development was placing upon them. In sentencing, for example, he took into account the fact that a jail sentence was in many cases a much greater hardship to an Eskimo or Indian than to a white person with a longer life expectancy, particularly if the sentence had to be served outside the Territories. During the early years, most of the work of his court involved criminal offences, often tried with juries, though the volume of civil work built up substantially during his tenure. 
Following a practice initiated by $\mathrm{Mr}$. Justice Sissons towards the end of his term of office, Morrow went out of his way to encourage applications for declaratory orders recognizing native adoptions; he thought that the Eskimo culture should be supported in this respect. He was pleased when he was upheld on appeal when one of his orders was challenged. He also held that adoptions by Indian custom were valid. ${ }^{32}$

One of his notable decisions was $R$. v. Tootalik ${ }^{33}$ which he heard as a magistrate. The charge was unlawfully hunting a female polar bear with young. The defence raised was that the incident took place outside the three-mile limit and that it was therefore outside his jurisdiction. Morrow however held that Canadian sovereignty extends to the sea ice and convicted. The decision was reversed on appeal, but on grounds relating to the wording of the ordinance.

The most notable of his decisions on the criminal side, however, was $R$. v. Drybones ${ }^{34}$ where he allowed a treaty Indian's appeal against a conviction for intoxication, holding that the special provisions of the Indian Act making it an offence for an Indian to be intoxicated off a reserve were invalidated by the provisions of the Canadian Bill of Rights which guarantee the right of the individual to equality before the law. His decision was upheld on appeal by the Court of Appeal ${ }^{35}$ and by the Supreme Court of Canada. ${ }^{36}$ The case is a landmark decision in connection with the Canadian Bill of Rights.

As a judge, Morrow could display the same fighting qualities that had marked him out as a lawyer, though again he exercised restraint when it was possible for him to do so. In 1973 the Registrar of Land Titles applied to him for advice and directions as to whether or not the Registrar should accept a caveat for registration. The caveat claimed aboriginal rights on behalf of the Indians and covered an unpatented area of the Northwest Territories. On the application, counsel for the Indians asked that an issue be directed with respect to the right to file a caveat, and Morrow decided that he should hold hearings to collect the facts relating to the Indian treaties and the impact of the proposed caveat. ${ }^{37}$ The Crown argued that his jurisdiction was restricted to giving a direction about the filing of the caveat. In view of his decision to go further the Crown applied to the Federal Court for a writ of prohibition on the grounds that Morrow was acting not as a judge of the Supreme Court of the Northwest Territories but as a persona designata under The Land Titles Act. Morrow perceived the Crown's action as a subversion of his court and maintained his position vigorously. Fortunately the Federal Court agreed with him and refused the writ of prohibition, ${ }^{38}$ and the case went on to be dealt with on its merits. ${ }^{39}$ Although the decision of the Supreme Court of Canada was

32. Re Indian Custom Adoptions, Re Beaulieu's Petition (1969) 67 W.W.R. 669.

33. (1969) 71 W.W.R. 435.

34. Supra n. 30.

35. (1967) 61 W.W.R. 370.

36. [1970] S.C.R. 282.

37. Re Paulette et al. v. Registrar of Titles (1973) 39 D.L.R. (3d) 45.

38. (1973) 39 D.L.R. (3d) 81.

39. Re Paulette et al v. Registrar of Titles (No. 2) (1973) 42 D.L.R. (3d) 8. 
to the effect that the caveat could not be filed and was therefore contrary to his own, ${ }^{40}$ he was satisfied that the authority of his court was vindicated.

One of his major undertakings as a judge was his Inquiry into the Administration of Justice in the Hay River Area of the Northwest Territories to which he was appointed Commissioner by federal Order-inCouncil. The inquiry arose because of a series of charges made by a local newspaper about the administration of justice in the Justices of the Peace Courts in Hay River. Morrow carried out a careful inquiry and concluded that, while the incumbent justices had many admirable qualities and had given devoted service, the circumstances of the time had changed to such an extent that they should be replaced. He went on however in characteristic fashion to make substantial recommendations for the improvement of the administration of justice throughout the whole of the Northwest Territories, with relation to facilities, Crown attorneys, legal aid, police administration, coping with the liquor problem, and the institution of an assistant deputy attorney general for the Northwest Territories with appropriate support. He also recommended that the Minister of Justice and the Solicitor General should themselves examine facilities in the Territories, an invitation which was accepted; indeed a substantial number of his 74 recommendations were accepted by the government. In making this inquiry, he based himself upon his unusual amount of experience as counsel for inquiries and commissions at all levels of government. These included the MacDonald-Mahaffy Commission of inquiry into allegations of misconduct in the provincial government; the Porter Commission inquiry into the civic administration of the City of Edmonton; an inquiry into the cost of the Edmonton Public Library on behalf of the City of Edmonton; and the Rand Inquiry into allegations about Mr. Justice L.A. Landreville of the Ontario High Court. Further, as a judge, he conducted other public inquiries in connection with the civic administrations in Edmonton and Calgary. He was acutely conscious of the dangers of the public inquiry, particularly the danger that reputations would be injured by false and malicious evidence. It was his practice to insist that every witness called before such an inquiry be interviewed in advance by Commission counsel and that evidence not be led unless it was necessary and relevant to the inquiry; damage to reputations would be reduced to the minimum consistent with the proper pursuit of the inquiry.

Bill Morrow's contribution to the development of the law in the Northwest Territories will be a lasting one. The reported cases record his approach to the developing law of that community. The changes that were wrought during his ten years of service seem to be as great as those which took place in Alberta in the 75 years surveyed by his paper. Throughout his service in the North he not only made significant contributions to the substantive and procedural law, but also ensured that the administration of justice was accorded a place of priority.

In 1976 he returned to Alberta to sit in the Alberta Court of Appeal. A place on that court was not his lifelong ambition; he had no lifelong ambi-

40. Paulette et al v. The Queen [1977] 1 W.W.R. 321. 
tion except to do his best in the fields in which his interests and fate put him. During his term on the Court of Appeal he displayed the same qualities he had shown before: industry, integrity and a devotion to the rule of law and to the ascertainment of what is just. He had another objective, which was to foster and maintain the integrity of the bar. That he accomplished not only by devotion of his time but by a conscious attempt to lead by example, and thus to teach lawyers and laymen alike of the true responsibility of a professional.

It is fitting that his last written work should have been destined for publication in the Law Review. For it is the younger members of the bar, and the students who are responsible for this publication, who must take up the great responsibility of the legal profession; and they have the most to gain from the examples of the leaders of that profession, men like the Honourable William George Morrow. 